Jurnal Ilmiah "Kreatif" Vol. XIV No. 1 Januari 2017

"Jurnal Studi Pemikiran Pendidikan Agama Islam"

\title{
EKSISTENSI KUTTAB DAN MASJID SEBAGAI INSTITUSI PENDIDIKAN PADA MASA PERTUMBUHAN ISLAM
}

\author{
Oleh: Fathurrahman
}

\begin{abstract}
Abstrak
Al-islamu sohihun likulli zaman wal makan adalah ungkapan yang menunjukkan bahwa Islam memiliki kemampuan adaptasi terhadap berbagai tempat dan situasi yang ada. Kuttab sebagai salah salah lembaga pendidikan pra Islam merupakan salah satu bentuk adaptasi dan modifikasi umat Islam terhadap warisan lama. Di tangan umat Islamlah kemudian kuttab mengalami perkembangan signifikan sebagai lembaga pendidikan yang terhormat dan bermartabat. Universalitas islam juga di tunjukkan melalui pengajar kuttab yang non muslim, tanpa mencampuri kesakralan pengajaran agama yang merupakan bagian penting dari pribumisasi islam dalam lembaga kuttab. Di samping mengadopsi lembaga pra Islam, keberadaan masjid sebagai bentuk asli dari lembaga pendidikan Islam awal merupakan cikal bakal dari munculnya lembaga-lembaga pendidikan Islam lainnya. Sebagai lembaga pendidikan, masjid tidak hanya berfungsi sebagai tempat ibadah. Namun juga menjalani fungsi social, politik, ekonomi dan budaya. Dalam perkembangan sejarah pendidikan Islam, modernisasi system pendidikan kuttab dan masjid inilah yang memunculkan munculnya lembagalembaga baru dalam pendidikan Islam.
\end{abstract}

Kata kunci: halaqa, syair arab, qur'an hadits, murid, syaikh.

\section{Pendahuluan}

Pada awal perkembangan Islam, pendidikan Islam formal yang sistematis belum terselenggara. Pendidikan yang berlangsung pada masa tersebut dapat dikatakan umumnya bersifat informal, dan lebih berkaitan dengan upaya-upaya dakwah islamiyah-penyebaran, dan penanaman dasar-dasar kepercayaan dan ibadah Islam.

Dalam kaitan itulah bisa dipahami kenapa proses pendidikan Islam pertama kali berlangsung di rumah sahabat-sahabat tertentu dan

\footnotetext{
*Penulis adalah Dosen Tetap Institut Agama Islam Muhammadiyah Bima. Email:
} fatunkbima@gmail.co.id 
Jurnal Imiah "Kreatif" Vol. XIV No. 1 Januari 2017

"Jurnal Studi Pemikiran Pendidikan Agama Islam"

yang paling terkenal adalah Dar al-Arqam. Ketika masyarakat Islam sudah terbentuk, maka pendidikan diselenggarakan di Masjid. Proses pendidikan di kedua tempat ini biasanya dilakukan dalam halaqah (lingkaran belajar). Masjid sebagai lembaga pendidikan Islam yang sudah ada sejak masa nabi, mempunyai peranan penting bagi masyarakat Islam sejak awal sampai sekarang. Dengan demikian, disamping berfungsi ibadah, masjid juga berfungsi sebagai tempat bersosialisasi dalam berbagai masalah dan sebagai tempat pendidikan. George Makdisi menengarai bahwa masjid merupakan institusi yang dipergunakan untuk kegiatan pengajaran atau pembelajaran sejak masa awal Islam. ${ }^{1}$

Lembaga lainnya pada masa awal pertumbuhan Islam yang terkait erat dengan pendidikan Islam dalam sejarah kaum muslimin adalah kuttab. Maktab atau kuttab adalah tempat-tempat untuk mengajar dan menulis dan dasar-dasar agama bagi anak-anak muslim. Lembaga ini telah dikenal masyarakat Arab pra-Islam sebagai lembaga tempat mengajarkan pengetahuan dan keterampilan membaca dan menulis. Pada zaman nabi, kuttab mulai dikenal pasca terjadinya perang Badar ketika Nabi menjadikan salah satu persyaratan pembebasan tawanan kafir Quraisy yang bisa baca tulis adalah dengan mengajarkan baca tulis bagi anak-anak Muslim di Madinah.

\section{Institusi Pendidikan Masjid}

1. Perkembangan Masjid Masa Awal Islam

Pada periode awal pendidikan Islam yaitu pada masa Rasulullah Saw. masjid memiliki peran signifikan dan strategis, baik ketika di Makkah atau di Madinah. Di Makkah, Masjid al-Haram menjadi tempat sosialisasi wahyu secara terbuka sehingga mengundang reaksi keras dari golongan musyrikin Quraisy seperti dialami oleh Abdullah ibn Mas'ud. Demikian pula sewaktu Nabi singgah di Quba dalam perjalanannya ke Yatsrib, selama 4 (empat) hari beliau mendirikan masjid yang kemudian dikenal dengan sebutan Masjid Quba, masjid yang pertama kali dibangun oleh nabi pada tahun ke-13 kenabiannya atau tahun ke-1 Hijriah (28 Juni 622 M).

Masjid Quba ini merupakan tempat peribadatan umat Islam pertama yang kemudian menjadi model atau pola dasar bagi umat Islam dalam membangun masjid-masjid di kemudian hari. Masjid Quba disamping sebagai tempat peribadatan yang menjadi fungsi utamanya, juga sebagai tempat pendidikan dan pengajaran agama

${ }^{1}$ George Maqdisi, The Rise of Colleges: Institution of Learning in Islam and the West, (Edinburgh: Edinburgh University Press: 1981), 21 
Jurnal Imiah "Kreatif" Vol. XIV No. 1 Januari 2017

"Jurnal Studi Pemikiran Pendidikan Agama Islam"

Islam. Untuk itu, Rasulullah menempatkan Mu'adz ibn Jabal sebagai imam sekaligus guru agama di Masjid Quba ini. Selain itu, Rasulullah sendiri kerap berkunjung ke masjid ini, baik dengan mengendarai unta ataupun berjalan kaki, dan menunaikan shalat. Kemudian setibanya di Yatsrib, langkah pertama yang dilakukan Rasulullah Saw. adalah membangun masjid yang sangat sederhana, berukuran $35 \times 30 \mathrm{~m}^{2}$ dengan berlantaikan tanah, dinding terbuat dari tanah yang dikeringkan, tiangnya dari batang pohon kurma dan atapnya dari pelepah dan daun. Masjid ini kemudian dikenal dengan sebutan Masjid Nabawi. Di sebelah timur masjid, dibangun tempat tinggal Rasulullah yang tentunya lebih sederhana lagi dari masjid, dan di sebelah barat dibangun sebuah ruangan khusus untuk orangorang miskin muhajirin, yang kemudian dikenal dengan sebutan al shuffah.

Di Masjid Nabawi inilah, fungsi-fungsi penting yang terkait dengan kehidupan masyarakat muslim pada masa itu dijalankan dengan baik karena Rasulullah sendiri yang secara langsung memimpin pemberdayaan masjid sebagai tempat dan basis utama mengelola masyarakat Muslim dengan sebaik-baiknya yang di kemudian hari melahirkan sebuah masyarakat ideal yang disebut masyarakat madani.

Selain dari dua masjid di atas, Rasulullah dan para sahabat juga membangun dan memperhatikan beberapa masjid dalam waktu yang berbeda antara lain: masjid Qiblatain, masjid Salman, masjid Sayyidina Ali, masjid Ijabah, masjid Raya, masjid Suqiya, masjid Fadikh, masjid Bani Quraizhah, Masjid Afr dan masjid al Aqsha yang notebene masjid tertua kedua setelah masjid al-Haram di Makkah.

Pada masa Khulafa al-Rasyidin juga dibangun beberapa masjid baru di wilayah-wilayah yang berhasil dikuasai. Di Bayt al Maqdis, misalnya, khalifah Umar ibn Khattab membangun sebuah masjid yang berbentuk lingkaran (segi delapan), dindingnya terbuat dari tanah liat, tanpa atap, tepatnya di atas bukit Muriah. Masjid ini kemudian dikenal dengan nama masjid Umar. Di Kufah pada tahun 17 H Sa'ad ibn Abi Waqqash, sebagai panglima perang, membangun sebuah masjid dengan bahan-bahan bangunan dari Persia lama dari Hirah dan selesai dibangun pada tahun $18 \mathrm{H}$. Masjid ini sudah memiliki mihrab dan menara. Di kota Basrah, pada tahun $14 \mathrm{H}$ juga dibangun sebuah masjid oleh 'Utbah ibn Ghazwan. Di Madain, pada tahun $16 \mathrm{H}$. Sa'ad ibn Abi Waqqash menjadikan sebuah gedung sebagai masjid. Di Damaskus, pada tahun 14 H. gereja St. John 
Jurnal Imiah "Kreatif" Vol. XIV No. 1 Januari 2017

"Jurnal Studi Pemikiran Pendidikan Agama Islam"

dibagi dua, sebagian (sebelah timur) menjadi milik muslim dan dibuat sebagai masjid oleh Abu Ubaidah ibn Jarrah. Di Fustat, Mesir, pada tahun $21 \mathrm{H}$. Amr ibn 'Ash, ketika menjadi panglima perang untuk menaklukan daerah tersebut membangun masjid al 'Atiq. Secara fisik masjid tersebut sudah berkembang lebih maju dibandingkan masjid-masjid lain yang telah ada. ${ }^{2}$

2. Fungsi Sosial Masjid

Dengan hijrahnya Nabi Muhammad Saw. ke Madinah merupakan pertanda bagi lembaga pendidikan yang baru dalam sejarah pendidikan Islam, di samping keluarga dan masyarakat. Lembaga pendidikan baru tersebut adalah masjid sebagai tempat yang pertama dibangun oleh Rasulullah bersama sahabat-sahabatnya itu yang menghimpun banyak kaum Muslimin. Di situlah mereka mengatur segala urusan, bermusyawarah guna mewujudkan tujuan, menghindarkan berbagai kerusakan dari mereka, saling membahu dalam mengatasi pelbagai masalah dan menghindarkan setiap kerusakan terhadap akidah, diri, dan harta mereka. Masjid adalah pusat umat berlindung kepada Rabb, dan memohon ketentraman, kekuatan serta pertolongan kepada-Nya. Di samping itu, masjid merupakan tempat umat Islam memakmurkan qalbu, dengan bekal baru berupa potensi-potensi ruhaniah. Dengan itu, Allah Swt. memberi umat Islam kesabaran, kekuatan, keberanian, kesadaran, pemikiran kegigihan dan optimisme.

Pada awal Islam, manakala ditimpa suatu musibah atau malapetaka, kaum muslimin segera berlindung kepada Allah Swt guna meninggikan panji Islam dan menegakkan kalimat Allah Swt. Secara bersama-sama, anak menerima pendidikan di masjid dalam naungan masyarakat Islam yang menunjukkan kebangkitan dan peningkatan. Masyarakat ini mengatur segala urusannya berdasarkan musyawarah, memantau para anggotanya yang sakit lalu menjenguknya, mengawasi para fakir miskin yang membutuhkan, lalu membantu mereka dengan apa yang terlah dikaruniai Allah padanya. Disini nampak tali kasih yang sangat mendalam diantara seluruh kaum Muslimin pada masa itu, sehingga menjadi suatu masyarakat yang kuat, saling berpegang erat dan berperan serta daam mendidik, membangkitkan serta menghidupkan generasi umat. Misalnya masjid Nabawi di Madinah telah menjalankan fungsinya hingga lahir peranan masjid yang beraneka ragama yaitu sebagai: (1)

${ }^{2}$ Makhmud Syafe'i, Masjid dalam Perspektif Sejarah dan Hukum Islam, http://file.upi.edu/direktori/FPIPS/M_K_D_U/195504281988031. Diakses pada 17 Desember 201 
Jurnal Imiah "Kreatif" Vol. XIV No. 1 Januari 2017

"Jurnal Studi Pemikiran Pendidikan Agama Islam"

Tempat ibada (sholat, zikir); (2) Tempat konsultasi dan komunikasi (masalah sosial, ekonomi, budaya); (3) Tempat pendidikan; (4) Tempat santunan sosial; (5) Tempat latihan militer dan persiapan alat-alatnya; (6) Tempat pengobatan korban perang; (7) Tempat perdamaian dan pengendalian sengketa; (8) Aula dan tempat menerima tamu; (9) Tempat menawan tahanan dan; (10) Pusat penerangan dan pembelaan agama.

Dengan menjalankan semua fungsi di atas, maka masjid menjadi lembaga pembinaan yang sangat penting memberi dampak edukatif terhadap perkembangan jiwa anak. Di dalam masjid, mereka mengamati orang-orang dewasa berkumpul berdasarkan kaidahkaidah yang bersumber dari Allah SWT. Bertambah dalam jiwa mereka perasaan diterima dan tergolong di dalam suatu kelompok yang mempunyai perasaan yang sama dalam masyarakat muslim dan rasa turut serta dalam kemuliaan jamaah Islamiyah. Di dalamnya mereka mendengar berbagai khutbah dan pelajaran ilmiah. Dengan bangkitnya kesadaran akan akidah Islam, anak-anak mulai menangkat makna tujuan hidup serta perangkat penata yang disediakan Allah dari masjid itu bagi mereka di dunia dan akherat.

Di dalam masjid mereka mempelajari dan menekuni membaca al-Qur'an. Melalui belajar membaca mereka memadukan perkembangan pikiran dan budaya dengan undang-undang kemasyarakatan Islam dan perkembangan rohani, yang akhirnya bermuara pada rasa keterikatan dengan pencipta mereka. Di dalam masjid mereka mempelajari hadits, fiqhi dan segala yang di kehendaki Allah SWT bagi manusia selaras dengan hidayah Allah serta sunnah rasul-Nya. Di dalam masjid mereka juga mempelajari ilmu-ilmu pelengkap seperti bahasa, sejarah Islam dan lain-lain yang dibutuhkan pada masa itu.

3. Sistem Pendidikan Masjid

Masjid dalam sejarah pendidikan Islam tidak hanya berfungsi sebagai tempat ibadah tetapi juga berfungsi sebagai pusat pendidikan dan kebudayaan. Masjid dalam fungsinya sebagai pusat pendidikan dan kebudayaan memainkan peranan yang penting pada periodeperiode pertama. Sebagai lembaga pendidikan, ia merupakan pusat tempat berlakunya proses pendidikan Islam. Di masjid-masjid didirikan dan diadakan tempat-tempat belajar baik di dalam masjid itu sendiri maupun di samping masjid dalam bentuk suffah atau kuttab. Masjid dalam fungsinya sebagai pusat kebudayaan, ia juga merupakan markas bagi kegiatan sosial, politik, budaya, dan agama. Di antara fungsi masjid sebagai pusat kebudayaan khususnya dalam 
Jurnal Imiah "Kreatif" Vol. XIV No. 1 Januari 2017

"Jurnal Studi Pemikiran Pendidikan Agama Islam"

kehidupan sosial dan politik yaitu sebagai pusat dalam pelaksanaan urusan kenegaraan seperti tempat melaksanakan pembaiatan para khalifah, tempat pertemuan dan tempat musyawarah. ${ }^{3}$

Fungsi masjid sebagai pusat kebudayaan yang disebutkan di atas berkurang pada masa bani Umayyah, karena para khalifah sudah menggunakan istana untuk fungsi tersebut. Sehubung sentralnya fungsi masjid sebagai lembaga pendidikan pada periode pertama ini, maka ia tidak saja digunakan sebagai tempat pendidikan orang dewasa (laki-laki), tetapi juga digunakan sebagai tempat belajar bagi kaum wanita dan anak-anak. Bagi orang dewasa, masjid berfungsi sebagai tempat belajar al-Qur'an, Hadits, fiqh, dasar-dasar agama, bahasa dan sastra Arab. Pendidikan dan pengajaran bagi kaum wanita diberikan satu kali seminggu. Mereka diajarkan al-Qur'an, hadits, dasar-dasar agama dan keterampilan menenun atau memintal. Pendidikan anak-anak juga diberikan di masjid serta suffah dekat masjid. Dalam pendidikan mereka disatukan tanpa adanya pembagian kelas. Anak-anak orang Islam yang sudah berumur enam tahun diharuskan belajar al-Qur'an, agama, bahasa Arab, dan berhitung dan untuk seterusnya diajarkan pula menunggang kuda, berenang dan memanah. Masjid sebagai tempat umum pendidikan anak ini pada umumnya tidak digunakan oleh anak-anak khalifah dan pangeran pada masa dinasti Umayyah. Anak-anak dididik di istana dan di rumah dengan cara mendatangkan tutor.

Pada masa nabi Muhammad Saw dan khalifah Abu Bakar Shiddiq masjid masih berfungsi sebagai tempat ibadah dan pendidikan Islam tanpa ada pemisahan yang jelas antara keduanya hingga masa Amirul Mukminin, Umar ibn Khattab. Pada masanya, di samping atau di beberapa sudut masjid dibangun kuttab-kuttab, untuk tempat belajar anak-anak. Sejak masa inilah pengaturan pendidikan anak-anak dimulai. Hari Jum'at adalah hari libur mingguan sebagai persiapan melaksanakan shalat Jum'at. Khalifah Umar ibn Khattab mengusulkan agar para pelajar diliburkan pada waktu dzuhur hari kamis, agar mereka bersiap-siap menghadapi hari Jum'at. Usul ini kemudian menjadi tradisi hingga sekarang. ${ }^{4}$

Sebagai institusi pendidikan Islam periode awal, masjid menyelenggarakan kajian-kajian baik dalam bentuk diskusi, ceramah dan model pembelajaran yang memiliki bentuk atau format tersendiri

\footnotetext{
${ }^{3}$ Muhammad Munir Mirsi, al-Tarbiyah al-Islamiyah, (Kairo: Dar al-Kutub, 1982), 199

4 Armai Arief (ed.), Sejarah Pertumbuhan dan Perkembangan LembagaLembaga Pendidikan Islam Klasik, (Bandung: Angkasa, 2014), 41
} 
Jurnal Imiah "Kreatif" Vol. XIV No. 1 Januari 2017

"Jurnal Studi Pemikiran Pendidikan Agama Islam"

yang disesuaikan dengan tingkat perkembangan masyarakat muslim pada masa itu yang pada masa-masa berikutnya terus mengalami inovasi dan pembaruan. Hasil inovasi dan pembaruan tersebut sebagai konsekwensi dari tuntutan dan kebutuhan masyarakat muslim terhadap pendidikan Islam yang terus mengalami perubahan dan peningkatan.

Format dasar pendidikan masjid adalah lingkaran studi, lebih dikenal dalam Islam sebagai `ilm al-halaqat 'atau singkatnya:halaqa. Halaqa, dieja halqa dalam edisi baru Ensiklopedi Islam, didefinisikan sebagai 'pertemuan orang yang duduk membentuk lingkaran. ${ }^{5}$

Lingkaran (halaqa) adalah bentuk tertua dari pengajaran Islam, sejak masa Nabi Muhammad, yang berperan memimpin kegiatan bagi para pengikutnya baik pria maupun wanita. Dalam halaqa tradisional, guru duduk di atas bantal membelakangi dinding atau pilar. Para siswa duduk dalam setengah lingkaran di sekitar guru, sesuai peringkat pengetahuannya. Pada awal Islam, para guru di halaqa termasuk laki-laki dan perempuan. Situs pertama untuk kalangan belajar berada di masjid (masjid). Guru terkenal dikaitkan dengan kota dan masjid tertentu, dan biasanya juga untuk nama pilar bagi ulama terkenal yang duduk di sana. Lingkaran belajar juga diadakan di lembaga lain dan rumah. Siswa melakukan perjalanan untuk duduk dalam lingkaran seorang sarjana terkenal. Tradisi merekam pemaparan pengajar berkembang menjadi pengajaran yang lebih sistematis. Metode yang dilakukan para guru dalam mengampu mata pelajaran, memungkinkan siswa mereka untuk mengajukan pertanyaan dan menguji pengetahuan mereka. Kesuksesan belajar dihargai dengan surat, atau sertifikat belajar (ijazah). Tradisi halaqa formal dan informal berlanjut sampai hari ini dalam kebudayan Muslim. ${ }^{6}$

Meski belum terstruktur, kelompok belajar yang disebut halaqa ini pada akhirnya berkembang menjadi lembaga formal. Pada mulanya seorang guru menjadi syaikh secara alami. Pada tahap selanjutnya dengan persiapan formal seorang syaikh halaqa dapat diangkat menjadi pengurus masjid. Pada akhirnya, syaikh halaqa berkembang menjadi penafsir yang menetapkan hukum sebagaimana

5 Saleh Zaimeche, Education in Islam - The role of the Mosque (United Kingdong: Foundation for Science Technologi and Civilation, 2002), 3.

6 Mehdi Nakosteen, Kontribusi Islam Atas Dunia Intelektual Barat: Deskripsi Analisis Abad Keemasan Islam, terj. Joko S. Kahhar (Surabaya: Risalah Gusti, 1995), 60-61 
Jurnal Imiah "Kreatif" Vol. XIV No. 1 Januari 2017

"Jurnal Studi Pemikiran Pendidikan Agama Islam"

termaktub dalam al Qur`an dan hadits. Pada tahap selanjutnya para ulama secara khusus diangkat menjadi guru agama dan memimpin berbagai halaqa sehingga sejarah lembaga pendidikan tinggi berikutnya berawal pada terbentuknya berbagai halaqa lainnya di berbagai masjid. ${ }^{7}$

Di dalam format pendidikan masjid berupa halaqa tersebut terdapat beberapa subjek pengajar yang masing-masing secara hirarkis memiliki tugas dan fungsi yang berbeda dan saling mendukung, yaitu: (1) Syaikh yang berarti guru utama yang juga disebut mudarris dan bertugas menjadi imam masjid pemimpin shalat jama'ah, khotib shalat jum'at, pengajar dan administrator dalam proses pendidikan masjid; (2). Na ib, sebagai asisten syaikh yang sewaktu-waktu menggantikan syaikh dalam mengajar jika syaikh berhalangan atau menunjuknya untuk mengajar; (3) Mu'id, sebagai juru ulang (repetitor) materi-materi yang telah diajarkan oleh syaikh atau mudarris kepada santri atau murid yang tidak sempat mengikuti pertemuan belajar, dan (4) Mufid, sebagai tutor yang bertugas membantu murid-murid yang lebih muda atau pemula tetapi belum dianggap mampu mengulang ceramah mudarris seperti halnya mu'id. ${ }^{8}$

Dalam halaqa yang diselenggarakan di masjid siapapun bisa bergabung baik statusnya sebagai murid yang terdaftar ataupun sekedar pengunjung yang berminat mengikuti kajian. Mereka yang menjadi murid pada halaqa tersebut diberi tugas untuk melakukan pembacaan terhadap sumber-sumber keilmuan penunjang agar tidak mengalami kesulitan dalam memahami uraian mudarris ketika proses kajian berlangsung, juga dituntut untuk berkonsentrasi secara sungguh-sungguh. Kegiatan diskusi aktif pun diintensifkan untuk menggali lebih dalam untuk menangkap wawasan lebih luas tentang ajaran Islam.

Salah satu diantara ciri-ciri utama kurun waktu tersebut adalah kemampuan untuk menghafal. Ketika itu terdapat banyak mudarris (ahli hadis) yang dapat membaca ulang sebuah hadis tanpa kesalahan sama sekali setelah hanya mendengar sekali saja. Hal ini mendorong lahirnya satu metode baru dimana hafalan merupakan bagian terbesar dalam latihan jiwa dan pembentukan kepribadian pada anak didik.

1989), 25

7 Mahmud Yunus, Sejarah Pendidikan Islam, (Jakarta : Hidakarya Agung,

8 Charles Michael Stanton, Pendidikan Tinggi dalam Islam, terj. H. Affandi dan Hasan Asy'ari, (Jakarta : Logos Wacana Ilmu, 1994), 47 
Jurnal Imiah "Kreatif" Vol. XIV No. 1 Januari 2017

"Jurnal Studi Pemikiran Pendidikan Agama Islam"

Metode lain dari cara pengajaran pada saat itu adalah guru menyampaikan pelajarannya dengan menggunakan frasa-frasa atau kalimat-kalimatnya satu persatu. Seorang asisten pengajar mengucapkan kembali keterangan yang telah disampaikan oleh seorang guru atau syaikh dengan suara keras, sehingga dapat didengar dan dicatat secara lengkap oleh para murid. Setelah itu sang guru atau syekh memulai berdiskusi dengan siswa yang duduk didekatnya, dan akhirnya lingkaran diskusipun berkembang. Kadangkadang guru juga berjalan di belakang para siswa dan ikut serta mendengarkan dan menyimak diskusi-diskusi mereka. Nilai yang diberikan oleh seorang guru ditentukan dengan ukuran seberapa jauh semua siswanya dapat mengikuti pelajarannya dengan baik. Setelah diskusi dan pelajaran selesai, para siswa untuk sementara waktu tetap bersama gurunya, dan mencoba mengambil manfaat dari kebersamaannya itu, sambil mencari inspirasi dari kehidupan sahabat yang memperoleh banyak ilmu pengetahuan hanya dengan berada bersama-sama Rasulullah Saw. ${ }^{9}$

Kadang-kadang dalam satu masjid terdapat beberapa halaqa dengan mudarris yang masing-masing mengajara satu ilmu, seperti ilmu tafsir, fiqih, tarikh dan sebagainya. Di masjid Amr ibn 'Ash (13 $\mathrm{H}$ ), misalnya, yang mula-mula diajarkan di masjid ini ialah pelajaran agama dan budi pekerti. Kemudian secara berangsur-angsur ditambahkan beberapa mata pelajaran. Pada waktu imam Syafi'i datang ke masjid ini untuk menjadi guru pada tahun $182 \mathrm{H}$, ia melihat sudah ada delapan buah halaqa yang penuh dengan pelajar. Pada masa Umayyah terdapat masjid sebagai pusat ilmu yakni Cordoba, masjid ash- Shahra, masjid Damaskus, dan masjid Qairawan. Pada masa Abbasiyyah, terdapat juga masjid sebagai pusat ilmu, periode pertama 132-232 H (750-847 M), yakni masjid Basrah, yang didalamnya terdapat halaqa al-Fadh, halaqa al Fiqh, halaqa al- tafsir wa al hadits, halaqa al-Riyadiyyah, halaqa al Sirr wa al- Adab (belum ada madrasah/sekolah). ${ }^{10}$

\section{Institusi Pendidikan Kuttab}

1. Kuttab Pra Islam

Maktab atau kuttab sesungguhnya merupakan sebuah tempat untuk belajar membaca maupun menulis, yang terletak di rumah guru

9 Hasarudin, Madrasah pada Masa Islam Klasik : Analisis Historis atas Metode yang Digunakan, (Hunafa : Jurnal Studia Islamika vol. 8, No. 1 Juni 2011), 130

10 Armai Rief, Sejarah Pertumbuhan 43 
Jurnal Imiah "Kreatif" Vol. XIV No. 1 Januari 2017

"Jurnal Studi Pemikiran Pendidikan Agama Islam"

dimana para murid berkumpul untuk menerima pelajaran. ${ }^{11}$ Sebagai mana telah dikatakan di atas, lembaga pendidikan Kuttab telah ada sejak masa Arab pra-Islam. Hal ini tentu saja terkait dengan kegiatan pendidikan yang berlangsung saat itu. Dengan merujuk kitab 'Uyun al-Akhbar karya Ibn Qutaibdah, tulisan M. Hamidullah, "Educational System in the Time of the Prophet", dalam Islamic Culture, yang dikutip Armai Arif menguraikan bahwa Zilmah, salah seorang perempuan anggota suku Hudhail, pada masa kecilnya memasuki sekolah dan biasa bermain-main dengan tinta yang dipakai untuk menulis. Selain, itu Ghailan ibn Salmah dari suku Taif juga terkenal sering mengadakan pertemuan mingguan di mana para penyair membacakan syair-syairnya dan mendiskusikan dan mengkritisi karya-karya mereka.

Di kota Makkah, kegiatan pendidikan juga berlangsung dengan standar yang lebih tinggi. Tujuh Mu'allaqat digantung di Ka'bah sebagai bukti keunggulan karya-karya tersebut. Waraqah Ibn Naufal adalah seorang penduduk Makkah yang menerjemahkan perjanjian Lama dan Baru ke dalam bahasa Arab. Menurut Hamidullah, kegiatan pendidikan juga dilakukan oleh para penganut Kristen dan Yahudi, dimana terdapat diwan (kumpulan syair) karya Samaw 'Adiya. Orang-orang Yahudi Manidah telah mendirikan Bait alMidras yang bertahan sampai masa Islam dan menjadi pusat kegiatan pendidikan dan agama. Selanjutnya, penggunaan kosa kata yang berkaitan dengan alat-alat tulis menulis atau giatan tulis menulis di dalam al-Qur'an seperti Qalam, nun, raqq, marqum, mastur, maktub dan sebagainya, menjadi bukti lain bahwa kegiatan pendidikan sudah berlangsung pada masa Arab pra-Islam. ${ }^{12}$

Penjelasan Hamidullah tersebut belum menunjukkan apakah kegiatan pendidikan tersebut bersifat massal atau hanya diikuti oleh orang-orang terntu. Dalam hal ini Ahmad Syalabi, dengan merujuk pada karya Al-Baladuri, Futuh al-Buldan menjelaskan bahwa Sufyan bin Umayya dan Abu Qais bin Abd Manaf adalah orang Arab asli pertama yang belajar membaca dan menulis. Guru mereka adalah seorang nasrani bernama Bishr 'Abd al-Malik yang telah belajar ilmu ini di Hira. Dan orang Arab pertama yang menjadi guru adalah Wadi al-Qurra yang hidup di sana dan memulai mengajarkan dan membaca

${ }^{11}$ Mehdi Nakosteen, Kontribusi Islam .........., 62

${ }^{12}$ M. Hamidullah, "Educational System in the Time of the Prophet", Islamic Culture, Januari, 1939 h. 48-50. Lih juga. Armai Arief, Sejarah Pertumbuhan 47 
Jurnal Imiah "Kreatif" Vol. XIV No. 1 Januari 2017

"Jurnal Studi Pemikiran Pendidikan Agama Islam"

dan menulis kepada penduduk Arab. Sehingga, pada saat datangnya Islam hanya ada 17 orang Quraisy yang mengenal tulis baca.

Dengan merujuk pada catatan yang ditulis oleh Syalabi ini dapat dikatakan bahwa kegiatan pendidikan membaca dan menulis itu hanya dilakukan oleh sekelompok orang dan khususnya di Makkah. Dan hal yang demikian dapat dimaklumi mengingat pada saat itu sebagaian penduduk di Jazirah Arab adalah penduduk yang memiliki kebiasaan hidup berpindah-pindah (nomaden). Tentu perhatian yang mereka berikan lebih besar pada pemenuhan kebutuhan-kebutuhan primer berupa makanan, sementara kegiatan pendidikan menjadi kebutuhan yang sekunder aau bahkan mereka anggap tidak penting sama sekali. Karena keterampilan membaca dan menulis belum menjadi hal yang umum dimiliki masyarakat, maka yang berkembang adalah tradisi lisan. Dalam kondisi seperti itu, yang menjadi 'guru' adalah mereka yang paling banyak memiliki hafalan. ${ }^{13}$

2. Kuttab Masa Islam

Dengan datangnya masa Islam, kegiatan pendidikan yang sudah ada sebelumnya dapat berkembang dengan lebih baik. Karena itu Ignaz Goldziher mengatakan "it may be safely said that Islam raised the Arabs to a higher level of civilization, and at the sametime introduced amongst them the elements of education, in which they had hitherto been rater deficient" 14 (tidak salah untuk dikatakan bahwa Islam mengangkat bangsa Arab ke tingkat peradaban yang lebih tinggi dan pada saat yang sama memperkenalkan elemenelemen pendidikan yang sebelumnya sangat memprihatinkan).

Perkembangan pendidikan pada masa ini tidak terlepas dari besarnya perhatian al-Qur'an pada pendidikan dan juga kebijakankebijakan yang diambil oleh Nabi sendiri dan anjuran-anjuran yang beliau sampaikan kepada umatnya berkaitan dengan urusan pendidikan. Misalnya, Rasulullah membebaskan tahanan setelah mengajarkan baca tulis kepada sekelompok Muslim. Di samping itu Rasulullah SAW juga memerintahkan al-Hakam bin Sa'id untuk mengajar pada sebuah kuttab di Madinah. ${ }^{15}$

Goldziher menyebutkan bukti-bukti adanya kegiatan pendidikan kuttab pada masa Nabi. Ummi Salim, ibu Anas bin Malik, asisten Rasullah (menurut sumber lain, Ummu Salamah, salah

${ }^{13}$ Stanton, Pendidikan Tinggi ..........., 14.

${ }^{14}$ Maksum, Madrasah sejarah dan Perkembangannya ......., 53-54.

15 Hasan Asari, Menyingkap Zaman Keemasan Islam, (Bandung: Mizan 1994), 24 
Jurnal Ilmiah "Kreatif" Vol. XIV No. 1 Januari 2017

"Jurnal Studi Pemikiran Pendidikan Agama Islam"

seorang istri Nabi), memintah seorang mu'allim kuttab untuk mengirimkan beberapa anak sekolah untuk membantu dia memintal wool. Kemudian Abu Hurairah, Ibn Umar dan Abu Usaid (yang ikut perang Badar) pada suatu saat melewati sebuah kuttab dan menarik perhatian anak-anak. Perkembangan lembaga pendidikan kuttab secara luas berlangsung pada awal bad ke 2 Hijriah, yakni sejak masa Muawiyyah. Menurut Hisyam Nashabi, perkembangan kuttab ini tidak bisa dilepaskan dari adanya kebutuhan keterampilan menulis sejalan dengan berkembangnnya kegiatan-kegiatan di kota-kota Islam baru; pencatatan al-Qur'an dan Hadits dan perkembangan lembaga-lembaga pemerintahan setelah adanya gerakan Arabisasi pada masa Umayyah.

3. Penyelenggaraan Pendidikan di Kuttab

Pendidikan pada awal Islam merupakan suatu yang alamiah terjadi, ketika ada orang yang bisa membaca dan kemudian bertemu dengan orang yang tidak tahu dan menghendaki belajar, maka terjadilah proses belajar. Maka sekolah bisa berlangsung di bawah pohon kurma di tenda atau dirumah. Menurut Ahmad Syalabi, pada mulanya pendidikan kuttab berlangsung di rumah-rumah para guru atau di pekarangan sekitar masjid.

Kuttab-kuttab tersebut juga sering merupakan wakaf dari orang kaya dan anak-anak yang belajar di sana tidak dipungut biaya atau kalaupun harus membayar dengan biaya yang sangat terjangkau oleh orang tua. Lebih dari itu, pendidikan kuttab juga terbuka untuk para budak. Dalam catatan A.L. Thibawi, keterlibatan pemerintah dalam pendidikan sangat kecil. "in neither the maktab nor the majlis did the state take any direct interest in the form of spending money from public fund, except perhaps when a qadi, holding public office, assumed responsibility for a majlis

a. Kurikulum Kuttab

Sejarah pendidikan Islam mencatat ada dua jenis kuttab pada zaman awal Islam. Kuttab jenis pertama dalah kutttab yang lahir masa pra-Islam tapi terus berlanjut setelah masa Islam. Kuttab ini mengajarkan tulis baca dan teks dasar puisi-puisi Arab, dan dengan sebagian besar gurunya orang-orang non Muslim.

Kuttab jenis kedua adalah kuttab yang berfungsi sebagai tempat pengajaran Al-Qur'an dan prinsip-prinsip Islam lainnya. Banyak di kalangan ilmuwan seperti halnya Philip K Hitti, Ahmad Amin dan Ignaz Goldzihr yang terjebak dengan menyamakan kedua jenis kuttab itu, sehingga akibatnya baik pelajaran baca tulis maupun pelajaran al-Qur'an dan pelajaran 
Jurnal Imiah "Kreatif" Vol. XIV No. 1 Januari 2017

"Jurnal Studi Pemikiran Pendidikan Agama Islam"

dasar-dasar agama lainnya diajarkan pada kuttab yang sama dan kemungkinan guru-guru non muslim mngajar baca tulis alQur'an kepada anak-anak Muslim. Menurut Ahmad Syalabi, kedua jenis kuttab ini terpisah. Kuttab jenis kedua tidak ditemui pada masa paling awal ketika kuttab jenis pertama sudah berkembang. Pengajaran al-Qur'an pada kuttab jenis kedua ini baru berkembang pada masa Umayyah setelah jumlah qurra dan huffadz telah banyak dan al-Qur'an telah banyak digandakan. Pada masa-masa sebelumnya pengajaran al-Qur'an berlangsung dalam halqah di masjid-masjid atau rumah-rumah secara informal. ${ }^{16}$

Kenyataan ini menunjukkan bahwa sejak Islam lahir, sudah terasa pentingnya baca tulis. Walaupun anak-anak muslim tidak pernah belajar al-Qur'an kepada guru-guru non Muslim, tetapi tidak demikian halnya dengn belajar baca tulis. Anak-anak muslim tidak mengapa belajar baca tulis kepada guru yang bukan orang muslim. Dengan demikian, syarat muslim untuk menjadi guru pada masa lalu tidak sepenuhnya benar dalam kondisikondisi tertentu. Rasul juga mempunyai perhatian terhadap pentingnya baca tulis waktu itu. Hal ini dibuktikan dua tindakan Rasul dalam hal ini, pertama, Rasul membebaskan tawanan perang Badr, setelah mereka mengajarkan tulis baca kepada sejumlah anak-anak Muslim. Kedua, Rasul memerintahkan AlHakam bin Sa'id untuk mengajar pada sebuah kuttab di Madinah.

Peserta didik di kuttab jenis pertama belajar baca tulis dengan teks dasar puisi-puisi Arab. Hal ini menunjukkan bahwa sebelum adanya al-Qur'an, puisi-puisi Arab sangat penting sebab biasanya berisi ungkapan bahasa yang halus dan mempunyai nilai etika yang tinggi. Rasul pun membanggakan dirinya karena pernah diasuh oleh Halimah al-Sa'diyah di suatu tempat yang bahasanya masih murni dan halus. Rasulullah berkata tentang masa silamnya sebagai berikut:

"Aku orang terpisah di antara kamu, dan aku seorang Quraisy yang dibesarkan di dusun keluarga Banu Sa'ad bin Bakr"

Pada masa-masa selanjutnya setelah kuttab jenis kedua, pelajaran terfokus kepada Al-Qur'an. Al-Qur'an dijadikan buku muthala'ah untuk belajar pelajaran membaca, dan kemudian

${ }^{16}$ Armai Arief, Sejarah Pertumbuhan dan Perkembangan 50 
Jurnal Imiah "Kreatif" Vol. XIV No. 1 Januari 2017

"Jurnal Studi Pemikiran Pendidikan Agama Islam"

memilih ayat-ayat al-Qur'an untuk dijadikan bahan pelajaran menulis.

Di samping belajar membaca dan menulis, mereka mulai belajar kaidah-kaidah bahasa Arab, kisah-kisah Nabi khususnya hadits-hadits Nabi. Di sini mulai terlihat pelajaran Al-Qur'an sudah mulai menggeser peran syair Arab, dan materi pelajaran lain lahir karena mendukung pelajaran al-Qur'an.

Pada masa selanjutnya, ketika Umar bin Khattab diangkat menjadi khalifah, beliau menginstruksikan kepada penduduk kota agar anak-anak diajari: berenang, mengendarai unta, memanah, membaca sya'ir dan peribahasa. Instruksi Umar ini hanya berlaku di tempat-tempat yang memungkinkan, misalnya belajar renang dapat dilaksanakan di kota-kota yang mempunyai sungai seperti Irak, Syam, Mesir dan lain-lain.

Pada perkembangan lebih lanjut, pelajaran di kuttab semakin berkembang, Muhammad Athiyah al-Abrasy mengemukakan sejumlah materi pelajaran kuttab yang meliputi: membaca al-Qur'an, menulis, pokok-pokok agama, bahasa, ilmu hitung dan tata bahasa. ${ }^{17}$

Tiap-tiap kuttab tidak menunjukkan keseragaman dalam memberikan mater pelajaran. Materi pelajaran yang diberikan di kuttab-kuttab bervariasi, tergantung pada kebutuhan daerah tertentu dan tentu saja tergantung pada kemampuan para ulamanya. Ibn Khaldun (w.808/1406 M) mencatat perbedaan praktik pendidikan kuttab pada masanya, sebagai berikut. Pertama, umat Islam al-Maghrib (Maroko) sangat menekankan pengajaran al-Qur'an. Anak-anak di daerah ini tidak akan belajar sesuatu yang lain sebelum menguasai al-Qur'an secara baik. Pendekatan mereka adalah pendekatan ontografi (mengenali satu bentuk kata dalam hubungannya dengan bunyi bacaan). Itulah sebabnya, menurut Ibn Khaldun, Muslim Maroko dapat menghafal al-Qur'an lebih baik dibanding Muslim dari daerah lain. Kedua, Muslim Spanyol (al-Andalus) mengutamakan menulis dan membaca. Al-Qur'an tidak diutamakan dibandingkan dengan puisi dan bahasa Arab. Penekanan pada pelajaran menulis melahirkan ahli-ahli kaligrafi yang dapat membaca dan menyalin al-Qur'an tanpa harus menghafalnya. Ketiga, daerah Ifraqiyah (Afrika Utara: Tunisia, al-Jazair dan Libya). Di sini pendidikan kuttab mengutamakan al-Qur'an

${ }^{17}$ Muhammad 'Athiyyat al-Abrasyi, Al-Tarbiyah al-Islamiyah, (tt: Dar' alFikr,ttg), h. 73. 
Jurnal Ilmiah "Kreatif" Vol. XIV No. 1 Januari 2017

"Jurnal Studi Pemikiran Pendidikan Agama Islam"

dengan tekanan khusus pada variasi bacaan (qira'at); lalu diikuti dengan seni kaligrafi dan hadits. Daerah keempat yang dibicarakan oleh Ibn Khaldun adalah daerah Timur (al-Masyriq= Timur Tengah, Iran, Asiah Tengah dan Semenanjung India) yang menurut pengakuannya -tidak ia ketahui secara jelas dibandingkan tiga daerah yang pertama. Secara umum daerah Timur ini menganut kurikulum campuran, dengan al-Qur'an sebagai inti; tetapi tidak memadukannya dengan keterampilan kaligrafi, sehingga tulisan tangan anak-anak Muslim dari Timur tidak begitu baik. ${ }^{18}$

Menurut Armai Arief, kurikulum kuttab pada zaman klasik menunjukkan hal-hal sebagai berikut:

1) Walaupun kuttab sudah ada sejak pra-Islam dan tujuan pertamanya untuk belajar baca tulis, tapi kemudian pelajaran Al-Qur'an menjadi tema penting pelajaran di kuttab. Tentu dengan pelajaran al-Qur'an ini tidak sekedar mmenuhi aspek kognitif saja, tetapi dimaksudkan untuk memenuhi aspek apektif, sehingga anak dapat mengapresiasi nilai-nilai al-Qur'an.

2) Masalah pendidikan akhlak amat diperhatikan, sebab hal ini merupakan aktualisasi dari pesan al-Qur'an. Lembaga pendidikan masa itu berarti lembaga pengawal moral. Pelanggaran moral merupakan pelanggaran berat, sehingga biasanya seluruh pelajaran- terutama pelajaran agama, selalu mengandung muatan moral.

3) Pelajaran seni, seperti seni tari dan seni musik tidak dikembangkan di kuttab. Mungkin seni-seni yang seperti ini dikhawatirkan dapat merusak akhlak anak.

4) Pelajaran-pelajaran lain di luar pelajaran a-Qur'an seperti tata bahasa Arab mungkin diberikan sebagai media untuk memahami al-Qur'an

5) Pelajaran olah raga dan berhitung belum mendapat keterangan yang rinci bagaimana materi dan pelaksanaannya di kuttab-kuttab.

6) Tidak terlihat adanya pelajaran yang benar-benar dapat dijadikan basis pengembangan sains pada jenjang pendidikan berikutnya. ${ }^{19}$

b. Guru

${ }^{18}$ Armai Arief, Sejarah Pertumbuhan .........., 51

${ }^{19}$ Armai Arief, Sejarah Pertumbuhan ........., 143 
Jurnal Ilmiah "Kreatif" Vol. XIV No. 1 Januari 2017

"Jurnal Studi Pemikiran Pendidikan Agama Islam"

Pada masa Islam awal, guru kuttab baik yang mengajar agama dianggap tidak selayaknya menuntut bayaran karena tujuan mengajar agama seharusnya hanya untuk mencari ridha Allah. Semua itu dilakukan dalam rangka ihtisaban (untuk mencari ridha Allah) bukan iktisaban (mencari penghidupan). ${ }^{20}$ Namun pada prakteknya guru-guru tersebut tetap mendapatkan bayaran, khususnya yang mengajarkan baca, menulis dan ilmu hitung. Namun mereka yang mengajarkan al-Qur'an pada umumnya menolak ketika diberi upah. Dengan mengutip pendapat Imam al-Gozali, Quraishi mengatakan: "Orang yang mencari kekayaan sebagai bayaran dari belajar itu seperti orang yang membersihan sepatunya yang kotor, tetapi kemudian mengusapkannya ke wajah sendiri; dia sama saja dengan membuat majikan menjadi budak dan membuat budak menjadi majikan". Pada kisah lain, diceritakan seorang imam Masjid Kufah, 'Abd al-Rahman al-Sullami suatu saat melihat sejumlah hewan ternak di rumahnya yang dikirim oleh seorang sebagai ungkapan terima kasih atas jasanya mengajar anaknya membaca Al-Qur'an. Seketika itu juga dia mengembalikan pemberian tersebut dan mengatakan "kami tidak akan mengambil bayaran dari pengajaran Kitab Allah".

Pada masa Umar guru-guru tersebut dibayar lima belas dirham, seorang guru itu bebas untuk menerima bayaran dari pemerintah, masyarakat atau perorangan, tetapi mereka harus puas berapapun bayarannya tergantung pada yang mau memberi. Bahkan dapur seorang guru itu terkenal karena isinya yang bermacam-macam. Besar atau kecil, baik atau jelek, tergantung pada kedermawanan orang tua murid. Akan tetapi guru tidak boleh menerima bayaran dari siswa tanpa sepengetahuan orang tua. Lebih dari itu, dia tidak boleh mencampuri urusan pekerjaan orang tua yang tidak sesuai dengan tuntutan agama, dan selama mereka masih melakukan pekerjaan tersebut, guru tidak boleh menemui mereka.

c. Murid

Beberapa sumber Abad Pertengahan memberikan informasi yang berbeda tentang usia anak memasuki pendidikan kuttab. Barangkali ini dapat juga dianggap sebagai pertanda tidak adanya ketentuan yang baku mengenai kapan anak dapat memasuki pendidikan kuttab. Ilmuwan Al-Andalus (Spanyol), Ibn Hazm

${ }^{20}$ Armai Arief, Sejarah Pertumbuhan ........, 52 
Jurnal Imiah "Kreatif" Vol. XIV No. 1 Januari 2017

"Jurnal Studi Pemikiran Pendidikan Agama Islam"

(w.456.1064) menganggap bahwa usia lima tahun adalah ideal untuk memulai pendidikan kuttab. Ibn al-Jawzi (w.597/1200) memberitakan bahwa ia memulai pendidikan kuttab-nya pada usia enam tahun, tetapi banyak diantara teman sekelasnya yang lebih tua dari dia sendiri. Seorang ulama bernama Ibn al-'Adim baru masuk kuttab pada usia tujuh tahun. Yang lain bahkan menunggu sampai berusia sepuluh tahun. Hal ini menunjukkan tidak adanya keseragaman mengenai kapan seorang anak harus memulai pendidikan kuttab-nya.

d. Metode Pengajaran

Metode pengajaran yang dipakai guru dalam pengajaran di kuttab masih sederhana. Metode pengajaran yang menekankan hafalan yang berkembang pada masa pra-Islam masih digunakan pada kuttab-kuttab masa Islam. Tritton memberikan gambaran bagaimana proses pengajaran berlangsung: guru membacakan teks, murid kemudian menuliskannya. Siswa kemudian membaca teks tersebut. Hubungan guru dan murid berlangsung layaknya hubungan orang tua dan anak. Kegiatan mengajar dilakukan dengan penuh kesederhanaan. Ketika garis besar materi sudah dikuasai murid, maka materi rinciannya diberikan kepada murid. Kesalahan-kesalahan yang dilakukan murid diperbaiki dengan santun. Tidak ada bukti guru-guru di sekolah Islam menyakiti siswa karena malas atau karena gagal dalam belajar. Pelajaran biasanya dilakukan pada pagi hari setelah matahari terbit dan berlangsung sampai siang hari.

Tampaknya apa yang disampaikan oleh Tritton mengenai hubungan guru dan murid itu sangat ideal, atau narasi tersebut lebih tepat disebut sebagai idealisasi dari praktek pendidikan di $k u t t a b$ waktu itu. Praktek pemberian hukuman fisik pada saat itu ada, meskipun bukan sebagai pilihan pertama. Menurut Goldziher pada saat itu cambuk dianggap sebagai alat pendidikan yang ada manfaatnya. Oleh karena itu guru sering diejek sebagai orang yang membawa pemukul (hamil dirra), dan Ibn Sina juga mengatakan a-ist'ana bi al-yad sebagai sesuatu yang berguna dalam pendidikan. Adanya pemberian hukuman fisik terhadap siswa ini tidak berarti bahwa para pendidik Muslim pada masa itu melihat hukuman sebagai alternatif pertama. Ibn Khaldun menjelaskan:

"severe punishment in the course of instruction does harm to students, especially to little children.... students hwo are brought up with injustice and (tyrannical) force are 
Jurnal Imiah "Kreatif" Vol. XIV No. 1 Januari 2017

"Jurnal Studi Pemikiran Pendidikan Agama Islam"

overcome by it. It makes them feel oppressed and causes them to lose their energy. It makes them lazy and induces them to lie and b insincere"

Kalimat Ibn Khaldun tersebut menunjukkan ketidaksetujuannya pada praktek pemberian hukuman fisik pada murid. Namun tidak menunjukkan bahwa hukuman fisik tidak pernah ada pada masa Islam dulu.

\section{Simpulan}

Keberadaan kuttab dan masjid merupakan salah satu bentuk keluwesan Islam dalam mengadopsi nilai-nilai positif dari tradisi lama pra Islam dan memunculkan bentuk-bentuk dalam pribumisasi Islam di masa awal pertumbuhan Islam. Kuttab merupakan bentuk dari adaptasi tradisi pra Islam dan masjid merupakan lembaga pendidikan Islam yang sui generis Lahir dari rahim umat Islam sendiri yang pada masa awal menjadi institusi sentral dan basis utama bagi pendidikan keummatan. Kelahiran insitusi-institusi pendidikan Islam periode berikutnya sesungguhnya adalah kelanjutan dari system pendidikan kuttab dan masjid.

\section{DAFTAR PUSTAKA}

Armai Arief (ed.), Sejarah Pertumbuhan dan Perkembangan LembagaLembaga Pendidikan Islam Klasik, (Bandung: Angkasa, 2014)

Charles Michael Stanton, Pendidikan Tinggi dalam Islam, terj. H. Affandi dan Hasan Asy'ari, (Jakarta : Logos Wacana Ilmu, 1994)

George Maqdisi, The Rise of Colleges: Institution of Learning in Islam and the West, (Edinburgh: Edinburgh University Press: 1981)

Hasan Asari, Menyingkap Zaman Keemasan Islam, (Bandung: Mizan 1994)

Hasarudin, Madrasah pada Masa Islam Klasik : Analisis Historis atas Metode yang Digunakan, (Hunafa : Jurnal Studia Islamika vol. 8, No. 1 Juni 2011)

M. Hamidullah, "Educational System in the Time of the Prophet", Islamic Culture, Januari, 1939

Mahmud Yunus, Sejarah Pendidikan Islam, (Jakarta : Hidakarya Agung, 1989)

Makhmud Syafe'i, Masjid dalam Perspektif Sejarah dan Hukum Islam, http://file.upi.edu/direktori/FPIPS/M_K_D_U/195504281988031.

Diakses pada 17 Desember 2016 
Jurnal Ilmiah "Kreatif" Vol. XIV No. 1 Januari 2017

"Jurnal Studi Pemikiran Pendidikan Agama Islam"

Maksum, Madrasah Sejarah dan Perkembangannya, (Jakarta: Logos Wacana Ilmu, 1999)

Mehdi Nakosteen, Kontribusi Islam Atas Dunia Intelektual Barat: Deskripsi Analisis Abad Keemasan Islam, terj. Joko S. Kahhar (Surabaya: Risalah Gusti, 1995)

Muhammad Munir Mirsi, al-Tarbiyah al-Islamiyah, (Kairo: Dar alKutub, 1982)

Saleh Zaimeche, Education in Islam - The role of the Mosque (United Kingdong: Foundation for Science Technologi and Civilation, 2002) 